\title{
Globalizációs folyamatoK TOPOLÓGIAI HATÁSA AZ OKTATÁSIRÁNYÍTÁSRA
}

\author{
KARDOS KATALIN \\ Debreceni Egyetem, Humán Tudományok Doktori Iskola \\ Nevelés- és Müvelődéstudományi Doktori Program \\ Beérkezett: 2021. október 17., elfogadva: 2021. november 18.
}

Steven Lewis: PISA, Policy and the OECD: Respatialising Global Educational Governance Through PISA for Schools. Singapore 2020. Springer, xix + 192 pp. DOI:10.1007/978981-15-8285-1

„Steven Lewis könyve több egymással öszszefüggő szempontból is jelentős mértékben járul hozzá az összehasonlító neveléstudományhoz és a politikai szociológiához (az oktatásban). A kötet tulajdonképpen egy - empirikus adatokon nyugvó, egyben a globalizáció új térbeliségi elméleteire, különösen a topológiára támaszkodó - könyvhosszúságú tanulmány. A szerző bevezetést nyújt a topológia elméleti kereteibe, valamint hozzásegíti az olvasót a politikai topológiával foglalkozó tudományok megértéséhez, szorosan kapcsolódva az oktatásszociológia témaköréhez" - írja Bob Lingard a könyv előszavában (p. 3.).

A könyv, amely a szerző éveken át tartó (2013-2018) kutatásainak és munkájának a csúcspontja, a PISA for Schools programot vizsgálja. Ennek a programnak az a kitüzött célja, hogy a PISA-méréseket jobban megismertesse a helyi szereplőkkel, illetve hogy egy-egy iskola a saját teljesítményét ún. PISA-alapú tesztek (PISA-Based Test for Schools) segítségével összehasonlíthassa másokéval, akár a különböző nemzeti oktatási rendszerek teljesítményével.

A szerző kutatómunkája - ugyanígy a jelen kötet - az alábbi három átfogó kérdés köré összpontosul:
- Milyen politikai lehetőségek és feltételek álltak az OECD rendelkezésére, amelyek keretében létrehozták és elömozdították a PISA for Schools programot?

- Hogyan alakítja át a PISA for Schools az OECD és az iskolák közötti kapcsolatot, a helyi és nemzeti oktatáspolitikákat?

- Hogyan használja az OECD a legjobb iskolai gyakorlat fogalmát, elősegíti-e a PISA for Schools a helyi oktatási reformok szabályozását?

A könyv hét fejezetre tagolódik. Az első fejezet a kutatás jellegét és irányát vázolja fel, bemutatja a kötet célját és ismerteti a további elemzéseket megalapozó empirikus adatokat. Steven Lewis itt konceptualizálja azokat a legfóbb fogalmakat, amelyek alapján értelmezni igyekszik a PISA for Schools programot: a helyi szintű oktatás globális szabályozásának újfajta gyakorlatának tekinti.

A második fejezet az OECD tágabb kontextusában helyezi el a PISA for Schools-t. $\mathrm{Az}$ OECD egyéb oktatási tevékenységeihez szorosan kapcsolódó programban - annak egyre növekvő jelentősége miatt 
- már egy önálló, globális politikai szereplőt feltételez. A fejezet átfogó jelentést ad a programról, amely az empirikus alapot nyújtotta a kutatáshoz és a kötet megírásához.

A harmadik fejezet részletesen leírja, milyen módon képesek olyan globális programok, „politikai formációk”, mint pl. a PISA for Schools, kibontakozni a helyi iskolai terekben. Tekintettel arra, hogy a kutatás igen nagy hangsúlyt fektet a „politikacsinálás" és a kormányzás kialakulóban lévő módjaira, tereire és kapcsolataira, valamint a helyi politikákra és politikai gyakorlatokra tett hatásaira, nem véletlen, hogy a szerző meglehetősen különböző szemléletmódokra támaszkodott, illetve új relációs vagy topológiai módszereket alkalmazott a térbeli viszonyok megértésének céljából.

Ezek közé tartozik a jelenkori kormányzás sokközpontú szerepének átgondolása, az új topológiai térrendszerek, a globalizációs folyamatokhoz kapcsolódó ésszerüségek és politikai erőviszonyok feltérképezése, valamint az, hogy ezek hogyan segítik elő a globális oktatás müködésének megismerését.

Ezt követően a szerző megvitatja, hogy a fentebb említett kapcsolati és hatalmi terek milyen hatást gyakorolnak a kritikai szemléletű szakpolitikai kutatásokra, vagyis, amennyiben a politikai tér topológiája valóban megváltozott, úgy milyen módon lehet az alkalmazott elemzési eszközöket és módszereket ezeknek a fejleményeknek az értelmezésére használni.

Ennek érdekében Steven Lewis olyan „topológiai” politikai szociológiát vázol fel, amely túlmutat a nemzetállamokon és kormányokon, hiszen azok többé már nem az egyedüli színterei a politikacsinálásnak, például megjelentek, és egyre fontosabbak a különböző nem állami/magán és nemzetközi szereplők (köztük a PISA for Schools is).
A fogalmi háttér megalapozását követi az elemző részek bemutatása, elsőként a negyedik fejezetben. A PISA for Schools példáján keresztül a szerző megvizsgálja az OECD társszervezeteinek szakpolitika hálózatát, beleértve azokat a jótékonysági alapítványokat, non- és forprofit oktatási vállalkozásokat, amelyek részt vettek a PISA az Iskolákért program (PISA for Schools) adminisztrációjában és finanszírozásában. Lewis interjú- és dokumentumelemzésekre támaszkodva vizsgálja, hogy ez a berendezkedési forma milyen módon pozícionálja az OECD-t az egyetlen csomópontként a kapcsolatok széles hálózatán belül, miként igyekszik az OECD - egyre újabb és újabb módszerekkel - oktatáspolitikai befolyását fenntartani és bővíteni világszerte. A fejezet ezt követően a politikai szereplők, magánszemélyek, ügynökségek fokozott szerepére és befolyására összpontosít az oktatáspolitikai körforgásban, valamint arra, hogy a PISA for Schools vitathatatlanul elősegíti olyan új terek megnyitását, amelyeken belül ezek a szervezetek tovább tudják vinni saját politikai programjukat a megvalósítás felé. Lewis mindamellett arra is törekszik könyvében, hogy megragadja azokat a változatos és néha ellentmondó érdekeket és motivációkat, amelyek a PISA for Schools tagjai és az iskolapolitikai hálózatok között húzódnak.

$\mathrm{A} z$ ötödik fejezet, a második elemző fejezet, azokat a változó térbeli kapcsolatokat vizsgálja, amelyeket a PISA tett lehetövé az iskolák számára, tükrözve a kortárs társadalmi gyakorlatok topológiai jellegét, beleértve az oktatást is.

A szerző szerint a PISA for Schools új kapcsolati folytonosságot hozott létre a pedagógusok és az iskolák között, valamint az iskolák és a nemzetközi (különböző nemzeti) iskolarendszerek között. Ezek a hasonlóságok képezik továbbá a különbségek azonosíthatóságának alapját is, mint 
például a hallgatói teljesítmények, pedagógiai gyakorlatok, politikai beállítódások, oktatási evidenciák.

A PISA for Schools új helyi szükségletek kialakítására, korábbi, elavult iskolai gyakorlatok megváltoztatására is ösztönzőleg hathat, hiszen lehetővé válik az egyes iskolák (nemcsak a nemzetközi PISA-mérésekhez kiválasztott néhány intézmény) számára, hogy saját magukat összehasonlítsák akár kimagaslóan eredményes iskolarendszerekkel is ( $\mathrm{pl}$. Sanghaj, Finnország). A PISA for Schools másrészt az OECD-nek is hasznos, hiszen segíti a helyi terek elérésében, az iskolák, az oktatás befolyásolásában.

A batodik fejezet, amely az utolsó az elemző fejezetek sorában, az új és hatékony („leghatékonyabb”) iskolai gyakorlatok megjelenésével és alkalmazásának módjaival foglalkozik. A szerző megvizsgálja, hogyan vett át az OECD "használatra kész" oktatáspolitikákat nagy teljesítményü iskolarendszerektől (Sanghaj, Szingapúr) a PISA for Schools keretében, kitérve arra, mi az, ami működőképes lehet a helyi iskolarendszerekben. Lewis ok-okozati összefüggéseket keres bizonyos magas színvonalú gyakorlatok és kívánatos iskolai programok között. Szakpolitikai csomagjában egyértelmü és következetes segítséget kínál a helyi oktatási reformok megértéséhez, amelyek a helyi iskoláztatás globális irányítását jelentik a legjobb iskolai gyakorlatokon keresztül. A fejezet továbbá azt is vizsgálja, hogy a PISA for Schools milyen módon járul hozzá az OECD globális politikájának terjesztéséhez a helyi iskolai terek között. A szerző azt állítja, hogy a professzionális tanulási közösségek a helyi oktatók és politikai döntéshozók számára olyan tereket biztosíthatnak, amelyek érdemi szakmai párbeszédet és együttműködést tesznek lehetővé. A fejezet végén felveti annak lehetőségét, hogy a PISA for Schools elösegítheti olyan al- ternatív szakpolitikai terek előmozdítását, amelyekből a pedagógusok visszacsatolást adhatnak a nemzeti és állami hatóságoknak, és ezáltal potenciálisan elősegíthetik az iskolai elszámoltathatóság hitelesebb megértését és rendeltetését.

A $z$ utolsó, hetedik fejezet összefoglalja a szerző kutatásainak általános eredményeit és felvázolja a kutatási témához való hozzájárulását empirikus, elméleti és módszertani meglátások tekintetében.

A kutatás feltárja az oktatáspolitika kortárs folyamatainak összetettségét, valamint azt, hogy hogyan képviseli a PISA for Schools a globális oktatásirányítás új kapcsolatait, térbeli tulajdonságait és módjait - miként burkolóznak tehát a nemzetközi diskurzusok és folyamatok iskolai szintü terekbe és szereplőkbe. A szerző megvitatja azt is, hogy a helyi pedagógusok hogyan tudnának eredményesebben bekapcsolódni az ehhez hasonló globális folyamatokba.

A kötet végén a szerző azon elmélkedik, vajon mit lehet külföldi oktatási rendszerek tanulmányozásából hasznosítani. A topológiai alapú szakpolitikai szociológiai megközelítés kidolgozása és felhasználása révén látható válik, hogy a PISA for Schools hogyan teszi lehetővé új kapcsolatok létesítését globális és iskolai szintű terek és szereplők között, valamint, hogy ez hogyan segítheti az oktatásirányítás és elszámoltathatóság új módozatainak előmozdítását. Lewis megjegyzi, hogy mindaz, amit az OECD oktatással kapcsolatos tevékenységében látunk, nem csupán az oktatáspolitika számszerű globális megnyilvánulása, hanem bizonyos mértékig a különböző iskolarendszerek nemzeti és kulturális sajátosságainak elismerése is egyben. Vizsgálatai azt sugallják, hogy az oktatók és közösségeik képesek lehetnek arra, hogy a PISA for Schools adatait felhasználva jelentős helyi reformokat és szakmai párbeszédeket mozdítsanak elöre. 
A könyv jelentős elméleti keretet nyújt az oktatáspolitikai kutatásokhoz a globális oktatásirányítással összefüggésben, a hálózatos vagy többközpontú kormányzás és az új globalizációt kísérő topológiai változások elemzéséhez. Lewis vizsgálatai megerősítik, hogy az OECD ma már olyan önálló oktatáspolitikai aktor az oktatás globális irányításának terén, amely a különböző szervezetein keresztül valamilyen szinten egységes, egymással összemérhető teret alkot. Lewis munkája nélkülözhetetlen alapot biztosíthat minden későbbi PISA-kutatáshoz, jelentős az elméleti és módszertani hozzájárulása a szélesebb körű oktatáspolitikai szakirodalomhoz, rálátást nyújt arra, hogy a helyi, nemzeti és globális folyamatok, milyen módon kapcsolódnak egymáshoz.

A cikk a Creative Commons Attribution 4.0 International License (https://creativecommons.org/licenses/ by-nc/4.0/) feltételei szerint publikált Open Access közlemény, melynek szellemében a cikk bármilyen médiumban szabadon felhasználható, megosztható és újraközölhető, feltéve, hogy az eredeti szerző és a közlés helye, illetve a CC License linkje és az esetlegesen végrehajtott módosítások feltüntetésre kerülnek. 